\title{
PENGARUH MODIFIKASI PERMAINAN FUTBAS TERHADAP KETEPATAN PASSING BOLA PADA SISWA EKSTRAKURIKULER FUTSAL SMA MUHAMMADIYAH 4 SURABAYA
}

\author{
Moh. Karimullah'1, Sumardi², Santika Rentika Hadi ${ }^{3}$ \\ 1,2,3 UNIPA Surabaya \\ E-mail: sumardi.ppi@gmail.com², santiklong@gmail.com³ \\ DOI: https://doi.org/10.36526/kejaora.v6i1.1233
}

\begin{abstract}
ABSTRAK
Penelitian ini bertujuan untuk mengetahui seberapa besar peningkatan ketepatan passing siswa pada ekstra kurikuler futsal dengan menggunakan metode futbas. Pelatihan ketepatan futsal dengan metode modifikasi ini untuk mempermudah guru ekstra futsal dan sebagai salah satu alternative metode modifikasi yang bisa digunakan oleh pelatih atau guru dalam aktivitas pembelajaran ekstra futsal. Penelitian ini menggunakan desain true experimental. Jadi cirinya ialah adanya kelompok kontrol dan sampel dipilih secara random. Dalam desain ini terdapat dua kelompok yang dipilih secara random, kemudian diberi pretest untuk mengetahui keadaan awal adakah perbedaan antara kelompok eksperimen dan kelompok kontrol. Penelitian ini menggunakan sampel siswa ekstra kurikuler futsal dengan jumlah 52 siswa yang terbagi dalam dua kelompok yaitu eksperimen dan kontrol dengan masing-masing jumlah 26 siswa dalam satu kelompok dengan menggunakan teknik random sampling. Dari hasil uji normalitas untuk mengetahi pengaruh permainan futbas terhadap ketepatan passing bahwa dari pre-test sebelum ada perlakuan pada hasil normalitas KolmogorovSmirnov sebesar 0,167 dan hasil $P$ Value lebih besar dari $a=0,05$, maka data terdistribusi normal. Untuk uji homogenitas Ternyata pengujian dengan statistik Based on Mean data pre-test diperoleh signifikansi 0,750 jauh melebihi 0,05. Untuk statistik Based on Mean data hasil post-test diperoleh signifikan 0,709. Dengan demikian data penelitian di atas homogen. Hasil dari penelitian terdahulu dibandingkan dengan ini tentang modifikasi permainan yang ada di sepak futsal yaitu dapat dijelaskan sebagai berikut mengkonsultasikan nilai $t_{\text {hitung }}$ dan nilai $t_{\text {tabel, }}$ maka dapat disimpulkan bahwa Ho ditolak dan Ha diterima karena $t_{\text {hitung }}>t_{\text {tabel }}$ atau nilai thitung $10,462>$ nilai tabel 1,708 dengan kata lain terdapat pengaruh permainan Futbas terhadap ketepatan passing boladi kelas XII di SMA Muhammadiyah 4 Surabaya data peningkatan hasil penelitian dari keterampilan awal pre-test ketepatan passing bola sampai post-test terdapat peningkatan sebesar $35 \%$.
\end{abstract}

Kata Kunci: Modifikasi, Futbas, Ketepatan Passing

\section{PENDAHULUAN}

Pendidikan bukanlah sesuatu yang bersifat statis melainkan sesuatu yang bersifat dinamis sehingga selalu menuntut adanya perbaikan yang dilangsungkan terus menerus. "Pendidikan dapat dimaknai sebagai proses mengubah tingkah laku anak didik menjadi manusia dewasa yang mampu hidup mandiri dan sebagai anggota mayarakat dalam lingkungan alam sekitar dimana individu itu berada" (Sagala, 2005).

Menurut John Dewey (Adang \& Agus, 2001) mengatakan "seorang pendidik yang mempunyai andil besar dalam kehidupan individu sehingga segala hal yang baru menjadi lebih terarah dan bermakna"Definisi ini mengandung arti bahwa pendidikan seseorang terdiri dari segala sesuatu yang dilakukan, dari mulai lahir sampai mati, berbuat atau mengerjakan sesuatu, sehingga seseorang belajar dengan cara melakukan segala aktivitas pendidikan yang dapat terjadi di kelas, perpustakaan, tempat bermain, perjalanan atau di rumah. Pendidikan jasmani adalah disiplin akademik yang bersifat disiplin pengembangannya sangat tergantung dari ilmu yang menyangga (psikologi, kesehatan filsafat, pendidikan, pengajaran dan sebagainya). Untuk dapat mengembangkan pendidikan jasmani sebagai disiplin ilmu, 
Jurnal Kejaora: Jurnal Kesehatan Jasmani dan Olah Raga

ISSN: 2541-5042 (Online)

ISSN: 2503-2976 (Print)

Volume 6 Nomor 1, Edisi April 2021

prasyarat mutlak yang harus dilaksanakan adalah insan akademik pendidikan jasmani untuk mengeksplorasi ilmu-ilmu penyangga, karena tanpa menguasi ilmu penyangga pendidikan jasmani akan semakin jauh tertinggal, karena pengembangan konsep dan teori ilmu penyangganya maju dengan pesat maka disitu kita dituntut agar menguasai ilmu tersebut. Dalam melaksanakan pembelajaran pendidikan seorang guru harus kreatif dan mampu merancang bentuk pembelajaran sesuai dengan perkembangan siswa (Candra \& Setiawan, 2020).

Belajar merupakan sebuah proses yang kompleks yang terjadi pada semua orang dan berlangsung seumur hidup. Salah satu tanda bahwa seseorang telah belajar sesuatu adalah adanya perubahan tingkah laku dalam dirinya. Dengan kata lain, pembelajaran lebih berorientasi pada aktivitas siswa untuk memperoleh hasil belajar berupa perpaduan antara aspek kognitif, afektif, dan psikomotor secara proposional (Widodo \& Widayanti, 2013).

Perkembangan olahraga saat ini sangat pesat, hal ini terlihat dengan semakin banyaknya kejuaran-kejuaran ditingkat daerah sampai tingkat nasional. Perkembangan olahraga ini dimulai dari cabang olahraga yang sudah sangat familiyar ataupun yang sangat bermsyarakat dan biasa kita temui atau dilihat di siaran Televisi nasional. Seperti halnya olahraga sepak bola, futsal, bola voli, basket, bulutangkis dan sebagainya, dan dari beberapa cabang olahraga yang popular tersebut olahraga futsal dan basket sangat menjadi favorit bagi anak- anak muda di Indonesia meskipun olahraga futsal dan basket kurang bermasyarakat seperti halnya permianan sepak bola karena permainan yang paling atraktif yang melibatkan banyak elemen didalamnya.Tapi nyatanya saat ini kedua olahraga tersebut yaitu futsal dan basket sudah mampu menarik anime masyarakat, apalagi dilingkungan kota yang saaat ini sangat jarang kita temukan ada lapangan sepak bola yang standart sehingga para pecinta oalahraga sepak bola lebih memilih menyewa lapangan futsal untuk melakukan permainan sepak bola karena kedua olahraga

tersebut hampir sama dalam segi permainannya.

Pendidikan jasmani, olahraga, dan kesehatan pada penjelasan Undang-Undang Sistem Pendidikan Nasional pasal 37 UU dituliskan, bahwa bahan kajian pendidikan jasmani, dan olahraga dimaksudkan untuk membentuk karakter peserta didik agar sehat jasmani dan rohani, dan menumbuhkan rasa sportivitas. Pendidikan jasmani, olahraga, dan kesehatan ditekankan untuk mendorong pertumbuhan fisik, perkembangan psikis, keterampilan motorik, pengetahuan dan penalaran, penghayatan nilai-nilai (sikap mental, emosional, sportivitas, spiritual, dan sosial).

Sesuai dengan penjelasan tersebut (Freeman, 2001) menyatakan bahwa pendidikan jasmani menggunakan aktivitas jasmani untuk menghasilkan peningkatan secara menyeluruh terhadap kualitas fisik, mental, dan emosional peserta didik. Pendidikan jasmani memperlakukan setiap peserta didik sebagai satu kesatuan yang utuh, tidak lagi menganggap individu sebagai pemilik jiwa dan raga yang terpisah, sehingga diantaranya dianggap dapat saling mempengaruhi. Pendidikan jasmani merupakan bidang kajian yang luas yang sangat menarik dengan titik berat pada peningkatan pergerakan manusia (human movement). Pendidikan jasmani menggunakan aktivitas jasmani sebagai wahana untuk mengembangkan setiap individu secara menyeluruh, mengembangkan pikiran, tubuh, dan jiwa menjadi satu kesatuan, hingga secara konotatif dapat disampaikan bahwa "suara pikiran adalah suara tubuh".

Menurut Mahendra mengemukakan bahwa secara sederhana pendidikan jasmani memberikan kesempatan kepada siswa untuk: (1) mengembangkan pengetahuan dan keterampilan yang berkaitan dengan aktivitas jasmani, perkembangan estetika, dan perkembangan sosial, (2) mengembangkan kepercayaan diri dan kemampuan untuk menguasai keterampilan gerak dasar yang akan mendorong partisipasinya dalam aneka aktivitas jasmani, (3) memperoleh dan mempertahankan derajat kebugaran jasmani yang optimal 
Jurnal Kejaora: Jurnal Kesehatan Jasmani dan Olah Raga

ISSN: 2541-5042 (Online)

ISSN: 2503-2976 (Print)

Volume 6 Nomor 1, Edisi April 2021

untuk melaksanakan tugas sehari-hari secara efisien dan terkendali, (4) mengembangkan nilai-nilai pribadi melalui partisipasi dalam aktivitas jasmani baik secara kelompok maupun perorangan, (5) berpartisipasi dalam aktivitas jasmani yang dapat mengembangkan keterampilan sosial yang memungkinkan siswa berfungsi secara efektif dalam hubungan antar orang, (6) menikmati kesenangan dan keriangan melalui aktivitas jasmani, termasuk permainan olahraga.

Dalam hal ini peneliti melakukan observasi terhadap siswa pada saat kegiatan ekstra kurikuler salah satunya ialah ekstra kurikuler futsal yang dari sekian banyak ekstra yang ada di SMA Muhammadiyah 4 Surabaya, ekstra futsal merupakan ekstra yang paling banyak diminati oleh siswa terutama siswa laki-laki mulai dari kelas $X$ sampai dengan kelas XII, pembentukan ekstra kurikuler sendiri bertujuan untuk mengembangkan minat dan bakat siswa pada jalur prestasi sehingga siswa mempunyai kesempatan diluar jam belajar sekolah untuk mengasah suatu kemampuan yang dimiliki dan dilatih khusus untuk lebih mengembangkan bakatnya pada cabangcabang olahraga tertentu. selain pada materimateri pembelajaran di sekolah, dalam hal ini penelti melakukan observasi terhadap siswa yang mengikuti ektra kurikuler futsal dan ditemukan suatu masalah dasar tentang turunnya prestasi yang ditorehkan oleh siswa SMA Muhammadiyah 4 di awal tahun dengan beberapa turnamen yang di ikuti selama awal tahun 2019 ini hanya sekali siswa SMA Muhammadiyah 4 Surabaya mendapatkan juara II diturnamen antar sekolah SMA Muhammadiyah di Surabaya yang diselenggarakan oleh SMAMuhammadiyah 4 Surabaya. ini semua tentu mendapat perhatian khusus tentang masalah yang terjadi ketika siswa sedang melangsungkan suatu pertandingan. Setelah dilakukan pengamatan ternyata masalah yang timbul dalam tim futsal tersebut ialah masalah dasar yang berkaitan dengan teknik dasar permainan futsal yaitu terletak pada kemampuan siswa pada saat melakukan passing bola yang terletak pada akurasi passing, karena dalam permainan futsal dengan jumlah pemain yang hanya berjumlah

5 orang dalam satu tim dengan ukuran panjang lapangan $25 \mathrm{~m}$ dan lebar $15 \mathrm{~m}$ maka diperlukan suatu teknik dasar passing dengan tingkat keakuratan diatas rata-rata dan kemampuan ini belum sepenuhnya dimiliki oleh siswa ekstra kurikuler futsal.

Setelah pengamatan dilakukan dan masalah sudah ditemukan maka peneliti disini ingin memberikan suatu treatment atau pelatihan kepada siswa ekstra kurikuler di SMA Muhammadiyah 4 Surabaya untuk meningkatkan kemampuan akurasi passing bola dalam permainan futsal, agar dapat mengembangkan kemampuan akurasi passing dalam permainan futsal maka peneliti memberi solusi atau cara bagaimana siswa bisa melatih suatu kekurangan itu dengan menggunakan suatu metode permainan karena jika hanya diprintah langsung akan timbul suatu kebosanan terhadap siswa yang mengikuti ekstra futsal tersebut, karena dalam segi psikomotor anak lebih tanggap melakukan suatu hal dengan cara yang tidak monoton harus dengan cara kreatif maka di sini peneliti menggunakan suatu permainan baru yaitu permainan Futbas (Futsal Basket) dengan cara bermaian dan peraturan yang sudah kami buat agar siswa dapat melakukannya dengan senang di lapangan tetapi tidak lepas dari tujuan utamanya ialah untuk meningkatkan kemampuan akurasi passing ketika mereka melangsungkan suatu pertandingan.

Sebagaimana hasil penelitian dari Kahansyah et al., (2018) yang mengemukakan jadi dengan permainan kita juga dapat mengombinasikan antara latihan dengan permainan. (Soniawan \& Irawan, 2018) metode bermain adalah metode yang mengajarkan suatu keterampilan psikomotorik dengan cara peragaan teknik kemudian mempraktikkannya dalam proses permainan. Olahraga ini dibuat agar lebih menarik dalam proses pembelajaran teknik dasar pasing bola untuk meningkatkan ketepatan passing dalam permainan futsal, di sini siswa dituntut bergerak aktif dalam melakukan passing kesasaran yang sudah ada. Beda dengan halnya yang biasanya melakukan tes ketepatan passing dengan hanya berdiri di belakang bola dan menendang bola selama 39 detik sebanyak 
Jurnal Kejaora: Jurnal Kesehatan Jasmani dan Olah Raga

ISSN: 2541-5042 (Online)

ISSN: 2503-2976 (Print)

Volume 6 Nomor 1, Edisi April 2021

mungkin ke arah papan sasaran

(Fenanlampir \& Faruq, 2015).

Olcay Mulazimoglu dalam Journalschool of physical education and sport menjelaskan bahwa teknik melakukan tes accuracy passing yaitu dengan menedang bola dengan jarak $15 \mathrm{~m}$ ke sasaran yang sudah disediakan.Yaitu berupa papan yang berukuran $1 \mathrm{~m}$. Permainan FUTBAS siswa harus bergerak aktif dalam melakukan permainan ini karena permainan ini adalah gabungan dari dua olahraga yang berbeda yaitu futsal dan basket yaitu bermain dengan teknik futsal tapi menggunakan peraturan yang ada dalam permainan bola basket dengan modifikasi alat sasaran permainan.

Berdasarkan pembahasan teoritis diatas, peneliti menjelaskan bahwa terdapat permasalahan seius yang harus diperhatikan dan diberikan solusi pada peserta ekstrakulikuler Futsal SMA Muhammadiyah 4 Surabaya. Hal tersebut dikarenakan kurangnya kemampuan ketepatan passing yang dimiliki. Kemampuan passing pada peserta ekstrakulikuler tersebut harus ditingkatkan karena akan berkontribusi terhadap nilai hasil belajar dan prestasi yang dicapai.

Berdasarkan uraian yang telah dikemukakan, dapat ditegaskan perlunya Modifikasi permainan dari cabang olahraga futsal dan basket. Adapun pelatihan ini digunakan untuk mengatasi permasalahan dalam kegiatan ekstra kurikuler futsal. Oleh karena itu, peneliti melakukan penelitian yang berjudul pengaruh modifikasi permainan futbas terhadap ketepatanpassing bola pada siswa ekstra kurikuler Futsal SMA Muhammadiyah 4 Surabaya.

\section{METODE}

Penelitian ini menggunakan desain true experimental, karena dalam desain ini, peneliti dapat mengontrol semua variabel luar yang mempengaruhi jalannya eksperimen (Arikunto, 2014). Desain penelitian dengan membagi dua kelompok yang dipilih secara random, kemudian diberi pretest untuk

Tabel 1. Deskripsi Hasil Permainan Futbas.

\begin{tabular}{lllllll}
\hline NILAl & Mean & SD & Varian & Max & Min & Peningkatan \\
\hline Pre-test & 30,81 & 3,131 & 9,805 & 39 & 25 & - \\
\hline
\end{tabular}


Jurnal Kejaora: Jurnal Kesehatan Jasmani dan Olah Raga

ISSN: 2541-5042 (Online)

ISSN: 2503-2976 (Print)

Volume 6 Nomor 1, Edisi April 2021

\begin{tabular}{llllllll}
\hline Ekperimen & 40,69 & 4,183 & 17,502 & 48 & 32 & $35 \%$ & \\
\hline Kontrol & 38,27 & 3,014 & 9,085 & 45 & 33 & $21 \%$
\end{tabular}

Tes awal (pre-test) sebelum diberikan perlakuan kepada siswa yaitu dengan tes ketepatan passing bola yang terdapat nilai rata-rata sebesar 30,81; Standart Deviasi sebesar 3,131; variance sebesar 9,805; skor maximal sebesar 39; skor minimal sebesar 25.

Penerapan permainan futbas terhadap ketepatan passing bola yang diberikan pada siswa terdapat nilai rata-rata sebesar 40,69; standart Deviasi sebesar 4,183; variance sebesar 17,502; skor maximal sebesar 48; skor minimal sebesar 32, dan peningkatan menggunakan pembelajaran permainan Futbas terhadap ketepatan passing bola maka pre-test dan post-test yaitu sebesar $35 \%$. Untuk kelompok kontrol hanya pemberian pembelajaran secara konvensional yang tujuannya sama yaitu untuk mengetahui ketepatan passing bola yang diberikan pada siswa terdapat nilai rata-rata sebesar 38,27; Standart Deviasi sebesar 3,014; variance sebesar 9,085; skor maximal sebesar 45 ; skor minimal sebesar
33, dan peningkatan menggunakan pembelajaran permainan Futbas terhadap ketepatan passing bola maka pre-test dan post-test yaitu sebesar $21 \%$.

Dari hasil uraian di atas dapat diketahui bahwa ada peningkatan menggunakan pengaruh permainan Futbas terhadap ketepatan passing bola.Hal ini terlihat dari nilai rata-rata post-test lebih tinggi dari pada nilai rata-rata pre-test. Hal ini berarti bahwa pembelajaran permainan Futbas terhadap ketepatan passing bolamemberikan hasil peningkatan yaitu sebesar $35 \%$.

Sebelum data diolah dengan analisis uji $t$ (dependent dan independent) data yang sudah didapat harus dianalisis dengan menggunakan uji Chi-Square. Uji ini dilakukan dengan melihat selisih yang diperoleh antara peluang komulatif dari observasi dengan peluang secara teoritis. Untuk menentukan apakah sebaran data normal atau tidak.

Tabel 2.Uji Normalitas Data

\begin{tabular}{clllll}
\hline \multirow{2}{*}{ Variabel } & \multicolumn{2}{l}{ Kolmogorov-Smirnov } & \multicolumn{2}{l}{ Shapiro-Wilk } & \\
\cline { 2 - 5 } & $P$ Value & $\alpha$ & $P$ Value & $\alpha$ & Hasil \\
\hline Pre-test & 0,167 & 0,05 & 0,272 & 0,05 & Normal \\
\hline Post-Test & 0,171 & 0,05 & 0,076 & 0,05 & Normal \\
\hline
\end{tabular}

Dari hasil uji normalitas di atas bahwa dari pretest sebelum ada perlakuan pada hasil normalitas Kolmogorov-Smirnov sebesar 0,167 dan hasil $P$ Value lebih besar dari $\alpha=0,05$, maka data terdistribusi normal. Uji normalitas pada hasil posttest menggunakan permainan Futbas terhadap ketepatan passing bola pada hasil normalitas Kolmogorov-Smirnov sebesar 0,171, maka data distribusi normal.
Setelah data berdistribusi normal, analisis dilanjutkan untuk mengetahui homogenitas data penelitian yaitu dengan uji homogenitas. Hasil uji homogenitas dengan program Statistical Package for Social Sciencefor windows release (SPSS 20) sebagai beri

Tabel 3. Uji Homogenitas

\begin{tabular}{cccl}
\hline Variabel & $\mathrm{F}_{\text {Hitung }}$ & $\mathrm{A}$ & Keterangan \\
\hline Pre-test & 0,750 & 0,05 & Homogen \\
\hline Post-test & 0,709 & 0,05 & Homogen \\
\hline
\end{tabular}


Ternyata pengujian dengan statistik Based on Mean data pre-test diperoleh signifikansi 0,750 jauh melebihi 0,05 . Untuk statistik Based on Mean data hasil post-test diperoleh signifikan 0,709.Dengan demikian data penelitian di atas homogen.

Untuk menjawab hipotesis yang telah diajukan, maka uji analisis yang dipergunakan dalam penelitian ini adalah uji beda rata-rata (uji beda mean) dengan menggunakan analisis uji Paired t-tes. Nilai yang digunakan dalam penghitungan uji $\mathrm{t}$ Paired t-test adalah nilai dari kelompok ekspenimen yaitu pemberian pembelajaran melalui permainan futbas terhadap ketepatan passing bola yaitu nilai dari pre-test dan posttest masing-masing kelompok. Hasil pengujian statistikk menggambarkan bahwa nilai $t_{\text {hitung }}$ dan nilai $\mathrm{t}_{\text {tabel, maka dapat }}$ disimpulkan bahwa $\mathrm{Ho}$ ditolak dan $\mathrm{Ha}$ diterima karena $t_{\text {hitung }}>t_{\text {tabel }}$ atau nilai $t_{\text {hitung }}$ $10,462>t_{\text {tabel }} 1,708$ dengan kata lain terdapat pengaruh permainan Futbas terhadap ketepatan passing boladi kelas XII di SMA Muhammadiyah 4 Surabaya. Cara yang kedua yaitu dengan melihat signifikan apabila penghitungan di bawah 0,05 maka terdapat pengaruh yang signifikan sedangkan signifikan lebih besar dari 0,05 ; maka tidak terdapat pengaruh yang signifikan. Berdasarkan tabel 4.4 didapatkan sig (2tailed) sebesar 0,000, maka didapat $0,000<$ 0,05 . dapat disimpulkan bahwa Ha diterima dan Ho ditolak jadi terdapat pengaruh permainan Futbas terhadap ketepatan passing bola kelas XII di SMA Muhammadiyah 4 Surabaya.

Setelah mengetahui hasil pengaruh permainan Futbas terhadap ketepatan passing bola, maka selanjutnya peneliti mengetahui data peningkatan hasil penelitian dari keterampilan awal pre-test ketepatan passing bola sampai post-test terdapat peningkatan sebesar $35 \%$.

Selanjutnya, uji beda rata-rata untuk sampel berpasangan pada kelompok kontrol dilakukan analisis dalam rangka menjawab hipotesis yang telah diajukan. uji analisis yang dipergunakan dalam penelitian ini adalah uji beda rata-rata (uji beda mean) dengan menggunakan analisis uji Paired t- tes. Nilai yang digunakan dalam penghitungan uji t Paired t-test adalah nilai dari kelompok kontrol yaitu pemberian pembelajaran melalui konvensional terhadap ketepatan passing bola yaitu nilai daripre-test dan post-test masing-masing kelompok. Nilai $t_{\text {hitung }}$ dan nilai tabel, maka dapat disimpulkan bahwa Ho ditolak dan Ha diterima karena $t_{\text {hitung }}>t_{\text {tabel }}$ atau nilai $t_{\text {hitung }} 8,941>t_{\text {tabel }} 1,708$ dengan kata lain terdapat pengaruh pembelajaran konvensional terhadap ketepatan passing boladi kelas XII di SMA Muhammadiyah 4 Surabaya.

Cara yang kedua yaitu dengan melihat signifikan apabila penghitungan di bawah 0,05 maka terdapat pengaruh yang signifikan sedangkan signifikan lebih besar dari 0,05 ; maka tidak terdapat pengaruh yang signifikan. Berdasarkan tabel 4.5 didapatkan sig (2-tailed) sebesar 0,000, maka didapat $0,000<0,05$; dapat disimpulkan bahwa Ha diterima dan Ho ditolak jadi terdapat pengaruh pengaruhpembelajaran konvensional terhadap ketepatan passing boladi kelas XII di SMA Muhammadiyah 4 Surabaya.

Setelah mengetahui hasil pada kelompok kontrol tanpa adanya perlakuan terhadap ketepatan passing bola, maka selanjutnya peneliti mengetahui data peningkatan hasil penelitian dari keterampilan awal pre-test ketepatan passing bola sampai post-test terdapat peningkatan sebesar $21 \%$.

Uji $t$ independen dilakukan untuk mengetahui perbedaan pembelajaran melalui permainan futbas dengan kelas kontrol tanpa adanya perlakuan terhadap ketepatan passing bola. nilai thitung dan nilai tabel, maka dapat disimpulkan bahwa Ho ditolak dan $\mathrm{Ha}$ diterima karena $t_{\text {hitung }}>t_{\text {tabel }}$ atau nilai $t_{\text {hitung }}$ 2,396> nilai tabel 2,021 dengan kata lain terdapat terdapat perbedaan pembelajaran melalui permainan futbas dengan kelas kontrol tanpa adanya perlakuan terhadap ketepatan passing bola di kelas XII di SMA Muhammadiyah 4 Surabaya.

Cara yang kedua yaitu dengan melihat signifikan apabila penghitungan di bawah 0,05 maka terdapat perbedaan yang signifikan sedangkan signifikanlebih kecil dari 0,05 ; maka terdapat pengaruh yang 
Jurnal Kejaora: Jurnal Kesehatan Jasmani dan Olah Raga

ISSN: 2541-5042 (Online)

ISSN: 2503-2976 (Print)

Volume 6 Nomor 1, Edisi April 2021

signifikan. Berdasarkan sig (2-tailed) sebesar 0,020 , maka didapat $0,020<0,05$. dapat disimpulkan bahwa $\mathrm{Ha}$ diterima dan $\mathrm{Ho}$ ditolak jadi terdapat perbedaan pembelajaran melalui permainan futbas dengan kelas kontrol tanpa adanya perlakuan terhadap ketepatan passing bola di kelas XII di SMA Muhammadiyah 4 Surabaya.

Berdasarkan uraian hasil analisis data, diketahui bahwa, hasil pengaruh permainan Futbas terhadap ketepatan passing bola.Hal tersebut dikarenakan metode latihan dengan modifikasi permainan cukup menarik bagi para peserta ekstrakulikuler. Mubaligin \& Candra, (2018) dalam penelitiannya berpendapat bermain juga bersifat serius karena bermain memberikan kesempatan untuk meningkatkan perasaan anak untuk menguasai sesuatu dan memunculkan rasa. Putra et al., (2019) melalui metode bermain yang digunakan untuk penelitian siswa dapat lebih menikmati pembelajaran yang berlangsung, sehingga siswa dapat mengeluarkan kemampuan yang dimilliki secara maksimal dan pembelajaran tersebut tidak membuat siswa bosan.

Sebagaimana hasil penelitian sebelumnya oleh Asbanu et al., (2018) bahwa penerapan metode bermain dalam proses latihan atau pada kegiatan ekstrakurikuler memiliki pengaruh yang sangat baik untuk peningkatan keterampilan passing bola futsal pada peserta didik. Dalam hasil penelitian Ardianto, (2016) untuk melaksanakan pembelajaran memerlukan persiapan yang cukup matang, sehingga guru harus mampu menentukan atau memilih topik dan memodifikasi permainan ataupun alat agar tidak terkesan terlalu monoton pada pembelajaran, yang benar-benar bisa di terapkan dalam proses belajar mengajar sehingga diperoleh hasil yang maksimal.

Maka selanjutnya peneliti mengetahui data peningkatan hasil penelitian dari keterampilan awal pre-test ketepatan passing bola sampai post-test terdapat peningkatan sebesar $35 \%$. Selanjutnya, hasil analisis terhadap kelompok kontrol, terdapat perbedaan pembelajaran melalui permainan futbas dengan kelas kontrol tanpa adanya

perlakuan terhadap ketepatan passing bola di kelas XII di SMA Muhammadiyah 4 Surabaya.

\section{KESIMPULAN}

Berdasarkan hasil analisis dan pembahasan yang telah diuraikan dapat disimpulkan bahwa, adanya pengaruh permaianan futbas terhadap ketepatan passing bola siswa kelas XII SMA Muhammadiyah 4 Surabaya. Selain itu, terdapat peningkatan pembelajaran melalaui permainan futbas terhadap ketepatan passing bola siswa kelas XII SA Muhammadiyah 4 Surabaya sebesar $35 \%$.

\section{UCAPAN TERIMA KASIH}

Penulis tidak lupa selalu bersyukur pada Allah SWT yang memberikan anugerah sehingga penelitian ini dapat terselesaikan tanpa kendala. Ucapan terimakasih pada semua yang telah terlibat dan membantu dengan tulus mulai dari perencanaan hingga penyelesaian laporan akhir penelitian.

\section{DAFTAR PUSTAKA}

Adang, S., \& Agus, M. (2001). Menuju Perkembangan Menyeluruh Menyiasati Kurikulum Pendidikan Jasmani di Sekolah Menengah Umum. Depdiknas. Ardianto, F. (2016). Meningkatkan pembelajaran passing sepakbola melalui modifikasi permainan crossbar colour pada siswa kelas $v$ sd negeri kertayasa 02 kecamatan kramat kabupaten tegal tahun pelajaran 2015/2016. Universitas Negeri Semarang.

Arikunto, S. (2014). Prosedur Penelitian Pendekatan Praktik.jakarta: Asdi mahasatya. Jakarta: Asdi mahasatya.

Asbanu, R., Kaswari, K., \& Triansyah, A. (2018). Pengaruh Metode Bermain Terhadap Hasil Passing Bola Futsal Pada Ekstrakurikuler SMPN 3 Pontianak. Jurnal Pendidikan Dan Pembelajaran Khatulistiwa, 7(4).

Candra, A. T., \& Setiawan, W. (2020). Meningkatkan Hasil Belajar Tolak Peluru Gaya Menyamping Menggunakan Alat Bantu Modifikasi Bola Kasti. Jurnal Pendidikan Kesehatan Rekreasi, 6(1). 
Jurnal Kejaora: Jurnal Kesehatan Jasmani dan Olah Raga

ISSN: 2541-5042 (Online)

ISSN: 2503-2976 (Print)

Volume 6 Nomor 1, Edisi April 2021

Fenanlampir, A., \& Faruq, M. M. (2015). Tes \& Pengukuran dala Olahraga. CV. Andi Offset.

Freeman. (2001). Pendidikan Jasmani. Depdikbud Dirjendikti.

Kahansyah, I., Subarjah, H., \& Supriyadi, T. (2018). Pengaruh Modifikasi Permainan Kucing-Kucingan Terhadap Kemampuan Passing Pada Permainan Sepak Bola. Jurnal Sportive, 3(1).

Mahendra, A. (2003). Falsafah Pendidikan Jasmani. Direktorat Pendidikan Luar Biasa.

Mubaligin, H., \& Candra, A. T. (2018). Upaya Peningkatan Hasil Lompat Jauh Gaya Jongkok Dengan Metode Bermain Lompat Dan Loncat Lingkaran Berjenjang Kelas VII MTs Negeri 11 Banyuwangi. Jurnal Kejaora, 3(1).

Putra, R. B. S., Mubin, D., \& Candra, A. T. (2019). Peningkatan Hasil Belajar Chest PassDengan Menggunakan Metode Bermain TrianglePada Siswa Kelas VIII MTsN Banyuwangi. Jurnal Kejaora, 4(1).

Sagala, S. (2005). Konsep dan Makna Pembelajaran Untuk Membantu Memecahkan Problematika Belajar dan Mengajar.

Soniawan, V., \& Irawan, R. (2018). Metode Bermain Berpengaruh Terhadap Kemampuan Long Passing Sepakbola. Jurnal Performa Olahraga, 3(01).

Widodo, \& Widayanti, L. (2013). Peningkatan Aktivitas Belajar Dan Hasil Belajar Siswa Dengan Metode Problem Based Learning Pada Siswa Kelas Viia Mts Negeri Donomulyo Kulon Progo Tahun Pelajaran 2012/2013. Jurnal Fisika Indonesia, XVII(49). 